\title{
Tolerance of Four Market Classes of Dry Beans to Tribenuron and Carfentrazone Applied Preplant
}

\author{
Nader Soltani*, Christy Shropshire, Peter H. Sikkema \\ Department of Plant Agriculture, University of Guelph, Ridgetown, Canada \\ Email: *soltanin@uoguelph.ca
}

How to cite this paper: Soltani, N., Shropshire, C. and Sikkema, P.H. (2021) Tolerance of Four Market Classes of Dry Beans to Tribenuron and Carfentrazone Applied Preplant. American Journal of Plant Sciences, 12, 558-565.

https://doi.org/10.4236/ajps.2021.124036

Received: March 3, 2021

Accepted: April 13, 2021

Published: April 16, 2021

Copyright $\odot 2021$ by author(s) and Scientific Research Publishing Inc. This work is licensed under the Creative Commons Attribution International License (CC BY 4.0).

http://creativecommons.org/licenses/by/4.0/

\begin{abstract}
Limited information is available on the sensitivity of dry beans to tribenuron and carfentrazone applied preplant (PP). Four field trials were conducted at Exeter and Ridgetown, ON, Canada in 2019 and 2020 to determine the tolerance of azuki, kidney, small red and white beans to glyphosate (1800 g.ae $\left.\cdot \mathrm{ha}^{-1}\right)$ + tribenuron (15 g.ai $\left.\cdot \mathrm{ha}^{-1}\right)$, glyphosate $\left(1800 \mathrm{~g} \cdot \mathrm{ae}^{\mathrm{a}} \mathrm{ha}^{-1}\right)+$ carfentrazone (35 g.ai $\left.\cdot \mathrm{ha}^{-1}\right)$ and glyphosate $\left(1800 \mathrm{~g} \cdot \mathrm{ae} \cdot \mathrm{ha}^{-1}\right)+$ tribenuron $\left(15 \mathrm{~g} \cdot \mathrm{ai} \cdot \mathrm{ha}^{-1}\right)+$ carfentrazone ( $35 \mathrm{~g} \cdot \mathrm{ai}^{\mathrm{i}} \mathrm{ha}^{-1}$ ) applied PP 1 - 2 days prior to seeding dry beans. Glyphosate + tribenuron, glyphosate + carfentrazone, and glyphosate + tribenuron + carfentrazone, applied PP, caused 5\%, 5\% and 9\% bean injury at $1 \mathrm{WAE} ; 7 \%$, $6 \%$ and $10 \%$ bean injury at $2 \mathrm{WAE}$ and $6 \%, 5 \%$ and $8 \%$ bean injury at 4 WAE, respectively. At $8 \mathrm{WAE}$, there was $0,1 \%$ and $4 \%$ injury in azuki bean; $1 \%, 2 \%$ and $2 \%$ injury in kidney bean; $3 \%, 2 \%$ and $3 \%$ injury in small red bean; and $6 \%, 3 \%$ and $2 \%$ injury in white bean with glyphosate + tribenuron, glyphosate + carfentrazone, and glyphosate + tribenuron + carfentrazone applied PP, respectively. The injury was significantly greater with glyphosate + tribenuron in small red and white beans compared to the azuki and kidney beans. There was no difference between injury levels among market classes of dry been with glyphosate + carfentrazone or glyphosate + tribenuron + carfentrazone applied PP. There was no effect of glyphosate + tribenuron, glyphosate + carfentrazone and glyphosate + tribenuron + carfentrazone on dry bean plant stand, maturity and seed yield. However, dry bean biomass was reduced as much as $15 \%$ with glyphosate + tribenuron and 13\% with glyphosate + tribenuron + carfentrazone compared to the untreated control. Dry bean height was reduced $4 \%$ with glyphosate + tribenuron + carfentrazone but was not affected with other treatments. Based on these results, there is potential for using glyphosate plus tribenuron or carfentrazone for preplant weed management in dry bean production.
\end{abstract}




\section{Keywords}

Azuki Bean, Kidney Bean, Small Red Bean, Sensitivity, Tolerance, White Bean

\section{Introduction}

Canada is a major dry bean producer in the world. Most of the dry bean produced in Canada is grown in Ontario. Dry bean growers in Ontario produced over 124,000 tonnes of dry beans on nearly 59,000 hectares with a farm gate value of nearly $\$ 115,000,000$ in 2019 [1]. Common market classes of dry beans produced in Ontario include azuki bean (Vigna angularis L.), kidney bean (Phaseolus vulgaris L.) small red bean (Phaseolus vulgaris L.) and white bean (Phaseolus vulgaris L.). Dry beans have short physical stature which makes them vulnerable to weed interference. Weeds can interfere with dry bean growth and development and cause substantial losses in seed yield and quality if not adequately controlled [2]. Weed interference has been shown to reduce seed yield of dry bean as much as $71 \%$ [1] which is substantially higher than $52 \%$ in soybean [3] and 50\% in corn [4]. Effective weed management practices that reduce weed interference and results in a concomitant increase yield and net returns are critical for dry bean growers to be competitive in the global market.

Annual, winter annual, biennial and perennial weed species that emerge early in the season can become very competitive and need to be controlled before dry bean is seeded. Preplant (PP) herbicides that provide effective control of troublesome weeds that are present at the time of seeding are needed to maximize yield especially under strip-, reduced-, or no-tillage cropping systems. The preplant herbicides can additionally decrease early season weed competition and minimize the need for early season postemergence (POST) herbicides which may be needed when weather conditions are not conducive for herbicide application [5]. Therefore, it is critical to develop new weed management strategies to control problematic weeds before dry bean is seeded. There are few herbicides registered for preplant burndown and residual weed control before seeding dry bean.

Tribenuron-methyl is a Group 2 herbicide that can be used with glyphosate for preplant burndown and residual broadleaf weed control in crops before seeding [5] [6]. Tribenuron is a sulfonylurea herbicide that in susceptible plants inhibits acetolactate synthase (ALS) or acetohydroxy acid synthase (AHAS) [6]. Tribenuron controls annual broadleaf weeds such as mustards (Sinapis spp.), common lambsquarters (Chenopodium album L.), henbit (Lamium amplexicaule L.), prickly lettuce (Lactuca scariola L.), kochia (Brassia scoparia subsp. densiflora), wild buckwheat (Polygonum convolvulus L.), volunteer canola (Brassica napus L.) including glyphosate-resistant biotypes and provides suppression of Canada thistle [Cirsium arvense (L.) Scop.]. Tribenuron is absorbed by both roots and shoots and moves within plants via xylem and phloem although the move- 
ment is primarily through phloem [6]. In susceptible plants, tribenuron inhibits the growth of treated plants within hours and plants die within 7 to 21 days [6]. Injury symptoms include chlorosis of the meristematic regions which is followed by total chlorosis and necrosis of sensitive plants over time [6]. Tribenuron has a relatively low use rate with low environmental, toxicological and eco-toxicological impact with minimal residual carryover as the herbicide persists in the soil for a short period of time [6]

Carfentrazone-ethyl, a Group 14 herbicide, can be used with glyphosate for the control of a wide spectrum of broad-leaf weeds applied as a preplant burndown in strip-, reduced- and no-tillage cropping systems [6]. Carfentrazone is an aryltriazinone herbicide that in susceptible plants inhibits protoporphyrinogen oxidase (PPO or Protox) [6]. Sensitive weeds to carfentrazone include pigweeds (Amaranthus spp.), common lamb-squarters, velvetleaf (Abutilon theophrasti Medic.), mallow (Malva sylvestris L.), nightshades (Solanum spp.), smartweed (Polygonum lapathifolium L.), tansy mustard (Descurainia pinnata L.), tall waterhemp (Amaranthus tuberculatus L.), cocklebur (Xanthium strumarium L.), jimsonweed (Datura stramonium L.), corn spurry (Spergula arvensis L.), kochia, volunteer canola, prickly lettuce and bur clover (Medicago polymorpha L.) [7]. Carfentrazone is very effective for the control of weed biotypes that are resistant to ALS-inhibitor herbicides. Carfentrazone has no residual activity and is absorbed primarily through shoots and is not readily translocated [6] [8]. In susceptible plants, carfentrazone injury symptoms appear within a few hours and plants become necrotic and die within a few days [6] [8]. Carfentrazone like tribenuron has a relatively low use rate and has low environmental, toxicological and eco-toxicological impact with minimal persistence in the soil [6].

Limited information is available on the sensitivity of various market classes of dry bean to glyphosate + tribenuron and glyphosate + carfentrazone or a tankmix glyphosate + tribenuron + carfentrazone applied preplant. Carfentrazone is very effective for the control of weed species that are resistant to ALS-inhibitor herbicides and is a desirable partner to be used with tribenuron which is an ALSinhibitor. If there is an adequate margin of crop safety, glyphosate in a mixture with tribenuron and carfentrazone can be an effective option for broad spectrum control of emerged weeds at the time of application including glyphosate- and ALS-resistant weed biotypes before dry bean is seeded.

The objective of this research was to determine the sensitivity of azuki, kidney, small red and white beans to glyphosate + tribenuron, glyphosate + carfentrazone and glyphosate + tribenuron + carfentrazone applied PP $1-2$ days prior to seeding.

\section{Materials and Methods}

Field trials (a total of 4 ) were conducted at the Huron Research Station near Exeter, ON, Canada and at Ridgetown Campus of the University of Guelph near Ridgetown, ON, Canada in 2019 and 2020 ( 1 trial per year at each site). The soil 
at Exeter was a Brookston clay loam (Orthic Humic Gleysol, mixed, mesic, and poorly drained) and the soil at Ridgetown was a Watford (Grey to Brown Brunisolic, mixed, mesic, sandy, and imperfectly drained)-Brady (Gleyed Brunisolic Grey to Brown Luvisol, mixed, mesic, sandy, and imperfectly drained) sandy loam.

The experiment was designed as a split-plot factorial, with four replicates; the whole plot factor was herbicide treatment and the split-plot factor was dry bean market class. Treatments included a non-treated control and glyphosate (1800 g.ae $\left.\cdot h a^{-1}\right)+$ tribenuron $\left(15 \mathrm{~g} \cdot a \mathrm{a} \cdot \mathrm{ha}{ }^{-1}\right)$, glyphosate $\left(1800 \mathrm{~g} \cdot \mathrm{ae} \cdot \mathrm{ha}^{-1}\right)+$ carfentrazone $\left(35 \mathrm{~g} \cdot \mathrm{ai} \cdot \mathrm{ha}^{-1}\right)$ and glyphosate $\left(1800 \mathrm{~g} \cdot \mathrm{ae} \cdot \mathrm{ha}^{-1}\right)+$ tribenuron $\left(15 \mathrm{~g} \cdot \mathrm{ai} \cdot \mathrm{ha}^{-1}\right)+$ carfentrazone $\left(35 \mathrm{~g} \cdot \mathrm{ai} \cdot \mathrm{ha}^{-1}\right)$ representing the $2 \mathrm{X}$ rates of the proposed use rates in dry beans. Sub-plots were market classes of dry bean which consisted of two rows of azuki bean ("Erimo"), kidney bean ("Dynasty"), small red bean ("Viper") and white bean (“T9905”) spaced $75 \mathrm{~cm}$ apart. Plots were $6 \mathrm{~m}$ wide at both locations and $8 \mathrm{~m}$ long at Ridgetown and $10 \mathrm{~m}$ long at Exeter. Dry beans were seeded at approximately $180-250$ thousand seeds $\mathrm{ha}^{-1}$ at a depth of $5 \mathrm{~cm}$ in late May to early June.

Herbicide treatments were applied PP to the soil surface one or two days before seeding. Herbicide treatments were applied with a $\mathrm{CO}_{2}$-pressurized backpack sprayer calibrated to deliver $200 \mathrm{~L} \cdot \mathrm{ha}^{-1}$ of spray solution at a pressure of $240 \mathrm{kPa}$ using low drift nozzles (ULD120-02, Spraying Systems Co., P.O. Box 7900. Wheaton, IL 60188). The boom was $2.5 \mathrm{~m}$ wide with six nozzles spaced 50 $\mathrm{cm}$ apart producing a spray width of $3.0 \mathrm{~m}$. The entire trial area including the non-treated control were kept weed-free with a PP application of glyphosate $\left(900 \mathrm{~g} \cdot a \mathrm{a} \cdot \mathrm{ha}^{-1}\right)+$ pendimethalin $\left(1000 \mathrm{~g} \cdot \mathrm{ai} \cdot \mathrm{ha}^{-1}\right)+$ imazethapyr $\left(37.5 \mathrm{~g} \cdot \mathrm{ai} \cdot \mathrm{ha}^{-1}\right)$ followed by hand hoeing and hand weeding as required.

Estimates of crop injury were evaluated 1,2, 4, and 8 weeks after emergence (WAE) using a scale of $0 \%$ to $100 \%$, where a rating of 0 was no plant injury and a rating of 100 was plant death. At $3 \mathrm{WAE}$, a $1 \mathrm{~m}$ section of row for each market class of dry beans was hand-harvested at the ground level, oven-dried, and the shoot dry weight (biomass) was recorded. Plant stand (number of plants per meter of row) was also counted at 3 WAE. At 5 WAE, ten plants from each market class of dry beans were randomly selected and the height from the soil surface to the highest growing point was measured. Yield was measured at maturity by combining both rows of each dry bean market class. Seed moisture content was adjusted to $18 \%$ for kidney, small red and white bean and $13 \%$ for azuki bean.

The GLIMMIX procedure in SAS [9] was utilized for data analysis. Fixed effects for the mixed model were herbicide treatment, dry bean market class and their interaction, while random effects consisted of environment (year-location combinations) and the interactions of replicate within environment, environment by herbicide treatment by dry bean market class and herbicide treatment by replicate within environment. All parameters except dry bean injury were converted to a percent of the untreated control prior to analysis. The normal 
distribution (identity link) was used to analyze dry bean injury and relative measures of plant stand, height and yield. Relative dry bean biomass per meter of row and per plant, as well as relative dry bean moisture at harvest were analyzed with the lognormal distribution (identity link). The distribution selected for each parameter was the one that best met the assumptions of the analysis. Studentized residual plots were used to check for departures from the assumption of homogeneous variance and the assumption of normality was confirmed using the normal probability plot and Shapiro-Wilk statistic from the UNIVARIATE procedure. Pairwise comparisons of least-square means were adjusted using the Tukey-Kramer method and the level of significance was set at $\mathrm{P}<0.05$. All data analysis was performed on the model scale; where the model and data scale differed, either the inverse link function or a back-transformation were used to obtain means on the data scale for presentation. In the cases where an environment had no injury, or where the untreated control was assigned a value of zero, they were excluded from the analysis due to zero variance. However, treatments could be compared to zero using the P-value from the LSMEANS output table, allowing comparisons with the untreated control for injury evaluations.

\section{Results and Discussion}

There was no interaction between the dry bean market classes and the herbicides evaluated for dry bean injury at 1,2 and $4 \mathrm{WAE}$, plant stand, dry weight/meter of row, dry weight/plant, height, maturity (as indicated by moisture content at harvest) and yield. For these parameters, the main effects of the herbicides will be presented (Table 1). There was an interaction between dry bean market classes and the herbicides for injury at 8 WAE so the simple effects will be presented for injury at 8 WAE (Table 2).

Sensitivity of dry market classes

At $1 \mathrm{WAE}$, glyphosate + tribenuron, glyphosate + carfentrazone, and glyphosate + tribenuron + carfentrazone applied PP caused greater injury in kidney bean than azuki and small red bean; white bean was intermediate and similar to other dry bean market classes (Table 1). At 2 WAE, glyphosate + tribenuron, glyphosate + carfentrazone, and glyphosate + tribenuron + carfentrazone applied PP caused greater injury in kidney bean than small red bean; azuki and white bean was intermediate and similar to other dry bean market classes. There was no difference among the four bean market classes in their response to tested herbicides at $4 \mathrm{WAE}$, plant stand, dry weight/meter of row, dry weight/plant, height, maturity (as indicated by moisture content at harvest) and yield.

\section{Effect of Herbicides}

Glyphosate + tribenuron, glyphosate + carfentrazone, and glyphosate + tribenuron + carfentrazone applied PP, caused $5 \%, 5 \%$ and $9 \%$ bean injury at 1 WAE; $7 \%, 6 \%$ and $10 \%$ bean injury at $2 \mathrm{WAE}$; and $6 \%, 5 \%$ and $8 \%$ bean injury at $4 \mathrm{WAE}$, respectively (Table 1 ).

Studies with other ALS-inhibiting herbicides applied preplant have shown up to $23 \%, 33 \%$ and $43 \%$ injury with chlorimuron and $17 \%, 18 \%$ and $29 \%$ injury 
Table 1. Response of four dry bean market classes to a preplant application of tribenuron, carfentrazone or their tankmix, as measured by crop injury and relative stand count, above ground biomass (dry weight) per m of row and per plant, height, moisture and yield, for four trials conducted at Exeter and Ridgetown, ON (2019-2020). Means for a main effect were separated only if the interaction involving the main effect was negligible. ${ }^{\mathrm{ab}}$

\begin{tabular}{|c|c|c|c|c|c|c|c|c|c|c|c|}
\hline \multirow[b]{2}{*}{ Main effects } & & \multicolumn{4}{|c|}{ Visible Injury $^{c}$} & \multirow{2}{*}{$\begin{array}{c}\text { Relative } \\
\text { Stand }\end{array}$} & \multirow{2}{*}{$\begin{array}{l}\text { Relative } \\
\text { /m row }\end{array}$} & \multirow{2}{*}{$\begin{array}{c}\text { biomass } \\
\text { /plant }\end{array}$} & \multirow{2}{*}{$\begin{array}{l}\text { Relative } \\
\text { Height }\end{array}$} & \multirow{2}{*}{$\begin{array}{l}\text { Relative } \\
\text { Moisture }\end{array}$} & \multirow{2}{*}{$\begin{array}{c}\text { Relative } \\
\text { Yield }\end{array}$} \\
\hline & & $1 \mathrm{WAE}$ & $2 \mathrm{WAE}$ & $4 \mathrm{WAE}$ & $8 \mathrm{WAE}$ & & & & & & \\
\hline & & \multicolumn{4}{|c|}{ 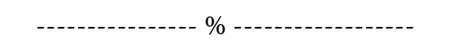 } & --------- & -1------- & - & $\%$----- & 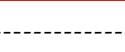 & -1--- \\
\hline \multicolumn{12}{|l|}{ Dry bean market class } \\
\hline Azuki & & $4.2 \mathrm{~b}$ & $5.6 \mathrm{ab}$ & 3.8 & 1.8 & 100 & 91 & $92 \mathrm{~b}$ & 99 & $99 \mathrm{~b}$ & $100 \mathrm{a}$ \\
\hline Kidney & & $9.1 \mathrm{a}$ & $11.1 \mathrm{a}$ & 9.4 & 1.6 & 98 & 93 & $107 \mathrm{a}$ & 97 & $100 \mathrm{ab}$ & $95 \mathrm{ab}$ \\
\hline Small Red & & $3.9 \mathrm{~b}$ & $4.6 \mathrm{~b}$ & 3.7 & 2.5 & 100 & 90 & $89 \mathrm{~b}$ & 97 & $101 \mathrm{a}$ & $100 \mathrm{a}$ \\
\hline White & & $7.0 \mathrm{ab}$ & $9.0 \mathrm{ab}$ & 8.5 & 3.6 & 92 & 83 & $88 \mathrm{~b}$ & 99 & $101 \mathrm{a}$ & $93 \mathrm{~b}$ \\
\hline BEAN P-value & & 0.0104 & 0.0279 & 0.0510 & 0.0016 & 0.4354 & 0.0898 & 0.0038 & 0.4188 & 0.0406 & 0.0036 \\
\hline \multicolumn{12}{|c|}{ Herbicide treatment ${ }^{d}$ Rate $\left(g\right.$ ai $\left.h a^{-1}\right)$} \\
\hline Untreated control & & $0 \mathrm{~b}$ & $0 \mathrm{~b}$ & $0 \mathrm{~b}$ & 0 & 100 & $100 \mathrm{a}$ & $100 \mathrm{a}$ & $100 \mathrm{a}$ & 100 & 100 \\
\hline Tribenuron-methyl & 15 & $4.9 \mathrm{ab}$ & $6.9 \mathrm{ab}$ & $5.6 \mathrm{a}$ & 2.3 & 95 & $85 \mathrm{~b}$ & $91 \mathrm{ab}$ & $99 \mathrm{a}$ & 101 & 99 \\
\hline Carfentrazone-ethyl & 35 & $4.7 \mathrm{~b}$ & $5.6 \mathrm{ab}$ & $5.1 \mathrm{a}$ & 2.1 & 98 & $97 \mathrm{a}$ & $101 \mathrm{a}$ & $99 \mathrm{a}$ & 99 & 97 \\
\hline $\begin{array}{l}\text { Tribenuron-methyl } \\
+ \text { carfentrazone-ethyl }\end{array}$ & $15+35$ & $8.5 \mathrm{a}$ & $10.3 \mathrm{a}$ & $8.3 \mathrm{a}$ & 2.7 & 98 & $87 \mathrm{~b}$ & $87 \mathrm{~b}$ & $96 \mathrm{~b}$ & 101 & 94 \\
\hline HERB P-value & & 0.0339 & 0.0671 & 0.2516 & 0.7544 & 0.7694 & 0.0139 & 0.0143 & 0.0269 & 0.1655 & 0.2237 \\
\hline \multicolumn{12}{|l|}{ Interaction } \\
\hline BEAN $\times$ HERB P-value & & 0.7364 & 0.9951 & 0.6263 & $<0.0001$ & 0.9934 & 0.3177 & 0.2625 & 0.6861 & 0.1514 & 0.8320 \\
\hline
\end{tabular}

${ }^{\mathrm{a}}$ Abbreviations: BEAN, dry bean market class; HERB, herbicide treatment; WAE, weeks after crop emergence. ${ }^{\mathrm{b}}$ Means followed by the same letter within a column are not significantly different according to a Tukey-Kramer multiple range test at $\mathrm{P}<0.05$. ${ }^{\mathrm{C}}$ Means for injury 1,2 and 4 WAE are based on data from Exeter in 2019 and 2020; injury 8 WAE based on data from Exeter in 2020 only. All remaining site-years showed no visible injury and were excluded from analysis due to zero variance. ${ }^{\mathrm{d}}$ All herbicide treatments included glyphosate $\left(1800 \mathrm{~g}\right.$ ae $\left.\mathrm{ha}^{-1}\right)$. Untreated control excluded from analysis due to zero variance; comparison of herbicide treatments with the value zero obtained from LSMEANS table in the Glimmix procedure.

Table 2. Response of four dry bean market classes to a preplant application of tribenuron, carfentrazone or their tankmix, as measured for crop injury 8 WAE at Exeter, ON $(2020) .^{\mathrm{ab}}$

\begin{tabular}{|c|c|c|c|c|c|c|c|c|c|}
\hline \multirow{3}{*}{ Herbicide treatment ${ }^{c}$} & & \multicolumn{8}{|c|}{ Injury $8 \mathrm{WAE}$} \\
\hline & Rate & \multicolumn{2}{|c|}{ Azuki } & \multicolumn{2}{|c|}{ Kidney } & \multicolumn{2}{|c|}{ SR } & \multicolumn{2}{|c|}{ White } \\
\hline & g ai ha ${ }^{-1}$ & --- & $\cdots$ & $\cdots$ & & ---- & -- & ----- & \\
\hline Untreated control & & $0 \mathrm{a}$ & & $0 \mathrm{a}$ & & $0 \mathrm{a}$ & & $0 \mathrm{a}$ & \\
\hline Tribenuron-methyl & 15 & $0 \mathrm{a}$ & $\mathrm{Z}$ & $0.8 \mathrm{ab}$ & $\mathrm{Z}$ & $3.0 \mathrm{~b}$ & $\mathrm{Y}$ & $5.5 \mathrm{c}$ & $\mathrm{Y}$ \\
\hline Carfentrazone-ethyl & 35 & $1.2 \mathrm{a}$ & & $2.0 \mathrm{~b}$ & & $2.0 \mathrm{~b}$ & & $3.2 \mathrm{bc}$ & \\
\hline $\begin{array}{c}\text { Trebernuron-methyl + } \\
\text { carfentrazone-ethyl }\end{array}$ & $15+35$ & $4.2 \mathrm{~b}$ & & $2.0 \mathrm{~b}$ & & $2.5 b$ & & $2.0 \mathrm{~b}$ & \\
\hline
\end{tabular}

aAbbreviations: SR, Small Red; WAE, weeks after crop emergence. ${ }^{b}$ Means followed by the same letter within a column $(\mathrm{a}-\mathrm{c})$ or row (Y-Z) are not significantly different according to a Tukey-Kramer multiple range test at $\mathrm{P}<0.05$. Rows without an uppercase letter have no differences among market classes. ${ }^{\mathrm{c} A l l}$ herbicide treatments included glyphosate ( $1800 \mathrm{~g}$ ae/ha). Untreated control excluded from analysis due to zero variance; comparison of herbicide treatments with the value zero obtained from LSMEANS table in the Glimmix procedure. 
with cloransulam-methyl in kidney, small red and white beans, respectively [10]. Cloransulam-methyl applied PRE at $70 \mathrm{~g}$ ai ha ${ }^{-1}$ has been shown to cause $9 \%$ visible injury at $1 \mathrm{WAA}$ and $13 \%$ visible injury at 2 WAA in dry beans [11]. However, in another study cloransulam-methyl applied PRE at $70 \mathrm{~g}$ ai ha ${ }^{-1}$ caused only $3 \%$ to $4 \%$ injury in pinto and small red dry bean 1 and 2 WAE [12]. Other researchers have reported as much as $13 \%$ crop injury with cloransulammethyl in dry beans [13].

There was no effect of glyphosate + tribenuron, glyphosate + carfentrazone and glyphosate + tribenuron + carfentrazone on bean plant stand, maturity and seed yield (Table 1 ). However, dry bean biomass/m of row and biomass/plant were reduced $15 \%$ and $9 \%$ with glyphosate + tribenuron and $13 \%$ and $13 \%$ with glyphosate + tribenuron + carfentrazone, respectively compared to the untreated control (Table 1). Dry bean height was reduced $4 \%$ with glyphosate + tribenuron + carfentrazone but was not affected with glyphosate + tribenuron or glyphosate + carfentrazone (Table 1). Other studies have shown that dry beans are very sensitive to glyphosate and tribenuron [14].

Effect of herbicide by dry bean market class

The analysis of simple effects for crop injury at $8 \mathrm{WAE}$ indicated $0,1 \%$, and $4 \%$ injury in azuki bean; $1 \%, 2 \%$ and $2 \%$ injury in kidney bean; $3 \%, 2 \%$ and $3 \%$ injury in small red bean; and $6 \%, 3 \%$ and $2 \%$ injury in the white bean with glyphosate + tribenuron, glyphosate + carfentrazone, and glyphosate + tribenuron + carfentrazone applied PP, respectively (Table 2 ). The injury was significantly greater with glyphosate + tribenuron in small red and white beans compared to azuki and kidney beans (Table 2). There was no difference in injury levels between market classes of dry been with glyphosate + carfentrazone, and glyphosate + tribenuron + carfentrazone applied PP (Table 2).

\section{Conclusion}

Based on these results, glyphosate + tribenuron, glyphosate + carfentrazone and glyphosate + tribenuron + carfentrazone applied PP can cause injury in azuki, kidney, small red and white beans. The injury was minimal with glyphosate + tribenuron and glyphosate + carfentrazone and decreased over time with no adverse effect on relative plant stand, biomass, plant height, maturity, and seed yield. However, injury with glyphosate + tribenuron + carfentrazone applied PP was more persistent and reduced plant height $4 \%$ and biomass $13 \%$. The injury was greater with glyphosate + tribenuron-methyl in small red and white beans compared to azuki and kidney beans. Based on these results, there is potential for using glyphosate plus tribenuron or carfentrazone for preplant control of emerged weeds in azuki, kidney, small red and white bean production. Further research is needed to ascertain the margin of crop safety with glyphosate + tribenuron + carfentrazone applied PP in azuki, kidney, small red and white beans.

\section{Acknowledgements}

Funding for this project was provided in part by the Ontario Bean Growers (OBG). 


\section{Conflicts of Interest}

The authors declare no conflicts of interest regarding the publication of this paper.

\section{References}

[1] [OMAFRA] Ontario Ministry of Agriculture and Food and Rural Affairs (2017) Area, Yield, Production and Farm Value of Specified Field Crops, Ontario, 2012-2017.

[2] Soltani, N., Dille, J.A., Burke, I.C., Everman, W.J., Van Gessel, M.J., Davis, V.M. and Sikkema, P.H. (2018) Potential Yield Loss in Dry Bean Crops Due to Weeds in the United States and Canada. Weed Technology, 32, 342-346. https://doi.org/10.1017/wet.2017.116

[3] Soltani, N., Dille, J.A., Burke, I.C., Everman, W.J., Van Gessel, M.J., Davis, V.M. and Sikkema, P.H. (2017) Perspectives on Potential Soybean Yield Losses from Weeds in North America. Weed Technology, 31, 148-154. https://doi.org/10.1017/wet.2016.2

[4] Soltani, N., Dille, J.A., Burke, I.C., Everman, W.J., Van Gessel, M.J., Davis, V.M. and Sikkema, P.H. (2016) Potential Corn Yield Losses from Weeds in North America. Weed Technology, 30, 979-984. https://doi.org/10.1614/WT-D-16-00046.1

[5] Jhala, A. and Sandell, L. (2014) Pre-Plant and Pre-Emergence Weed Control in Corn and Soybeans. Pre-Plant and Pre-Emergence Weed Control in Corn and Soybeans.

[6] Shaner, D. (2014) Herbicide Handbook. 10th Edition, Weed Sci, Champaign.

[7] [OMAFRA] Ontario Ministry of Agriculture and Food and Rural Affairs (2020) Guide to Weed Control, Publication 75. Toronto, 1-457.

[8] [OMAFRA] Ontario Ministry of Agriculture and Food and Rural Affairs (2009) Ontario-CropIPM-Carfentrazone.

http://www.omafra.gov.on.ca/IPM/english/weeds-herbicides/herbicides/carfentrazo ne.html

[9] [SAS] Statistical Analysis Systems (2014) The SAS System for Windows, Release 9.4. Statistical Analysis Systems Institute, Cary.

[10] Soltani, N., Shropshire, C. and Sikkema, P.H. (2019) Sensitivity of Dry Bean to Herbicides Applied Preplant for Glyphosate-Resistant Horseweed Control in a StripTillage Cropping System. Weed Technology, 33, 178-184. https://doi.org/10.1017/wet.2018.107

[11] Soltani, N., Shropshire, C. and Sikkema, P.H. (2010) Tolerance of Black, Cranberry, Kidney, and White Bean to Cloransulam-Methyl. Weed Biology and Management, 10, 33-39. https://doi.org/10.1111/j.1445-6664.2010.00364.x

[12] Sikkema, P.H., Robinson, D.E., Nurse, R.E. and Soltani, N. (2008) PRE-Emergence Herbicides for Potential Use in Pinto and Small Red Mexican Bean (Phaseolus vulgaris) Production. Crop Protection, 27, 124-129. https://doi.org/10.1016/j.cropro.2007.04.017

[13] Van Gessel, J.M., Monks, W.D. and Quintin, R.J. (2000) Herbicides for Potential Use in Lima Bean (Phaseolus lunatus) Production. Weed Technology, 14, 279-286. https://doi.org/10.1614/0890-037X(2000)014[0279:HFPUIL]2.0.CO;2

[14] Sawchuk, J.W. (2003) The Influence of Simulated Herbicide Drift on Canola (Brassica napus L.) and Dry Bean (Phaseolus vulgaris L.). University of Manitoba, Manitoba, $126 \mathrm{p}$. 